\title{
CHARACTERISTICS OF SOARING BIRDS' SPRING MIGRATION OVER INLAND SE BULGARIA
}

\section{Značilnosti spomladanske selitve jadrajočih ptic v notranjosti JV Bolgarije}

\author{
Peter Shurulinkov ${ }^{1}$, Girgina Daskalova ${ }^{2}$, Nayden Chakarov ${ }^{3}$, Krassimir Hristov ${ }^{4}$, Silvia \\ Dyulgerova $^{2}$, Yana Gocheva 2 , Svilen Cheshmedzhiev ${ }^{2}$, Minko Madzharov ${ }^{2} \&$ Ivallo Dimchev $^{2}$ \\ ${ }^{1}$ National Museum of Natural History, Bulgarian Academy of Science, Tsar Osvoboditel 1, BG-1000 Sofia, Bulgaria, \\ e-mail: shurulinkov@mail.bg \\ ${ }^{2}$ Bulgarian Society for Protection of Birds, jk.Yavorov, bl. 71, BG-1111 Sofia, Bulgaria, e-mail: girginand@mail.bg \\ ${ }^{3}$ Department of Animal Behavior, University of Bielefeld, D-337501 Bielefeld, Germany, \\ e-mail: az.nayden@googlemail.com \\ ${ }^{4}$ Balkani Wildlife Society, Tsanko Tserkovski 67b, BG-1000 Sofia, e-mail: hristov_k@abv.bg
}

We investigated the scale and characteristics of spring migration of soaring birds in Bourgas district, SE Bulgaria during three 5-day periods in March $\left(27^{\text {th }}-31^{\text {st }}\right)$, April $\left(20^{\text {th }}-24^{\text {th }}\right)$ and May $\left(12^{\text {th }}-16^{\text {th }}\right) 2008$. Simultaneous counts were carried out from six observation points in two separate areas (Karnobat and Sredets), located $24.5 \mathrm{~km}$ and $37.3 \mathrm{~km}$ inland from the Black Sea coast, respectively. In total, 31,049 soaring birds of at least 27 species were counted, by far the most numerous being the White Stork Ciconia ciconia (23,358 ind.), followed by the Lesser Spotted Eagle Aquila pomarina (3,112 ind.). In Karnobat area, situated farther from the Black Sea coast, the total number of soaring migrants $(21,231)$ was more than two-fold higher than in Sredets area $(9,818)$. Overall, there was a significant difference in flock size and flight altitude within separate area (i.e. among observation points) as well as between the two observation areas and the three 5-day periods. However, there was a substantial variance in factors significantly affecting the flock size and flight altitude among most numerous individual species. In general, birds passed at much higher altitude above Karnobat area (mean flight altitude $208.3 \mathrm{~m} \pm$ 6.4) compared to Sredets area (mean flight altitude $130.5 \mathrm{~m} \pm 4.4$ ). In both observation areas, northern direction was the most commonly observed flight direction (46.3\% of all recorded flight directions). The highest numbers of soaring migrants passed in the late afternoon, between 15.00 and $18.00 \mathrm{hrs}$ - 11,554 individuals (43.0\% of all birds counted). The study confirmed that the front of Western Black Sea migration route, or "Via Pontica" as part of the Mediterranean/Black Sea Flyway in SE Bulgaria, is rather wide, since the magnitude of inland migration in Bourgas district can be compared with that along the Black Sea coast, at least during spring migration. Both observation areas qualify as Important Bird Areas (IBA) of European importance according to the several BirdLife International criteria. We recommend that any new wind farms built should avoid the area of Hisar Hill south of Karnobat and the NW parts of Sredets Municipality.

Key words: migration, soaring birds, Via Pontica, wind farms, SE Bulgaria Ključne besede: selitev, jadrajoče ptice, Via Pontica, vetrne elektrarne, JV Bolgarija 


\section{Introduction}

Studies on the main bird migration routes of the Eurasian-African migration system, especially along its eastern branches, were conducted mostly on a few well known sites - the so-called "migration bottlenecks" where high concentrations of large, diurnal soaring migrants were reported. Examples for such sites along the Mediterranean/Black Sea Flyway are Bourgas area, Bulgaria, Bosphorus, Borcka and Belen Pass, Turkey, Eilat, Israel, Suez Strait and Zayt Bay Desert, Egypt (Curry-Lindahl 1984, Simeonov et al.i 990, Michev et al. I999, Zalles \& Bildstein 2000, Newton 2008, HiLgerLOH 2009). Usually, these sites lie along routes where topography favours development of thermals used by soaring migrants, i.e. in narrow coastal areas and straits. To date, fewer investigations were completed inland, especially on the Balkan Peninsula, which is crossed by one of the major branches of the Mediterranean/Black Sea Flyway - Western Black Sea Route or "Via Pontica".

Several ornithological studies conducted along the western Black Sea coast showed great significance of the latter as one of the most important bird migration routes in Europe. Most of the concrete published figures giving basic data for this migration route are available for autumn migration from Bosphorus (Turkey) and from Bourgas Bay and Kaliakra and Emine Capes in Bulgaria (Porter \& Willis i968, Konigstedt \& Robel i982, Michev et al. I987 \& i999, Dimitrov et al. 2005, Kostadinova \& Gramatikov 2007). Data on spring migration along the western Black Sea coast are scarce (GYLLIN I97I, RoberTS I978 \& I98I, Zalles \& Bildstein 2000). Because earlier studies mainly concentrated on rather narrow belt along the Black Sea coast, questions about the numbers of birds passing further inland and the westernmost limits of this migration route remain open.

Recently, this question became particularly important after many projects for installation of wind farms along the Black Sea coast and its vicinity were discussed and part of them already prematurely implemented, mostly in Kavarna Municipality in NE Bulgaria. These inadequately positioned wind farms already led to killing of some rare and endangered species by collision, e.g. Eagle Owl Bubo bubo, Crane Grus grus and Griffon Vulture Gyps fulvus (http://bspb.org/show2.php?id=1706\&menu_id=33, own data). Wind farms can cause significant mortality and have other negative impacts on birds, reported by many studies on this topic. Negative impacts on birds are mostly confined to collision risk, disturbance and displacement, barrier effect and habitat loss or degradation (DrewitT et al. 2006, European Commission 2010). Data from many existing wind farms in Western Europe and North America emphasize the great importance of spatial planning of the wind farms for the degree of negative impact on birds (Noguera et al. 20 Io). Thus, wind farms situated along important migration routes and especially on migration bottleneck sites can be detrimental to bird populations (DrewitT \& LANGSTON 2006). Among bird species, most vulnerable to collisions with wind turbines are diurnal raptors and storks (MADDERS \& Whitfield 2006, European Commission 2010), which predominate among soaring migratory birds in Mediterranean/Black Sea Flyway (NewTON 2008).

The unclear picture about magnitude of inland migration along Via Pontica leads many decision makers to the conclusion that wind farms installed some kilometres inland from the shore do not pose danger to migrants. However, Kostadinova \& Gramatikov (2007) as well as radar investigations by Michev et al. (1987) showed that in NE Bulgaria and in Strandzha Mts (SE Bulgaria) Via Pontica migration route extends well inland with tens and even up to hundreds of kilometres. Unfortunately, neither of these studies covered central and western parts of the Bourgas district.

Thus, in this study our aim was to obtain actual data on the scale of spring migration of soaring birds in inland parts of SE Bulgaria and to present some characteristics of the observed migration in those areas. We had no objective to count the total numbers of the passing migrants over the whole area but rather to compare the migration intensity and other parameters between two different areas. One of our questions was whether there was a reduction in migrant numbers at some distance from the coast as it could be expected in the case some earlier assumptions proved true, and if so, whether this was true for all studied species and what was the extent of this reduction. Furthermore, we wanted to estimate the importance of potential collision risk of birds with man-made structures.

\section{Study area and methods}

Six points were chosen for observation of spring migration in SE Bulgaria, representing two separate observation areas (Figure 1). Three of them were in Sredets Municipality, between the town of Sredets and the village of Suhodol (UTM NG09 \& NG19, herein referred to as "Sredets area") and three other points in Karnobat Municipality, on Hisar Hills between the town of Karnobat and the village of Kozare (UTM $\mathrm{MH} 92$, herein referred to as "Karnobat area"). In both 


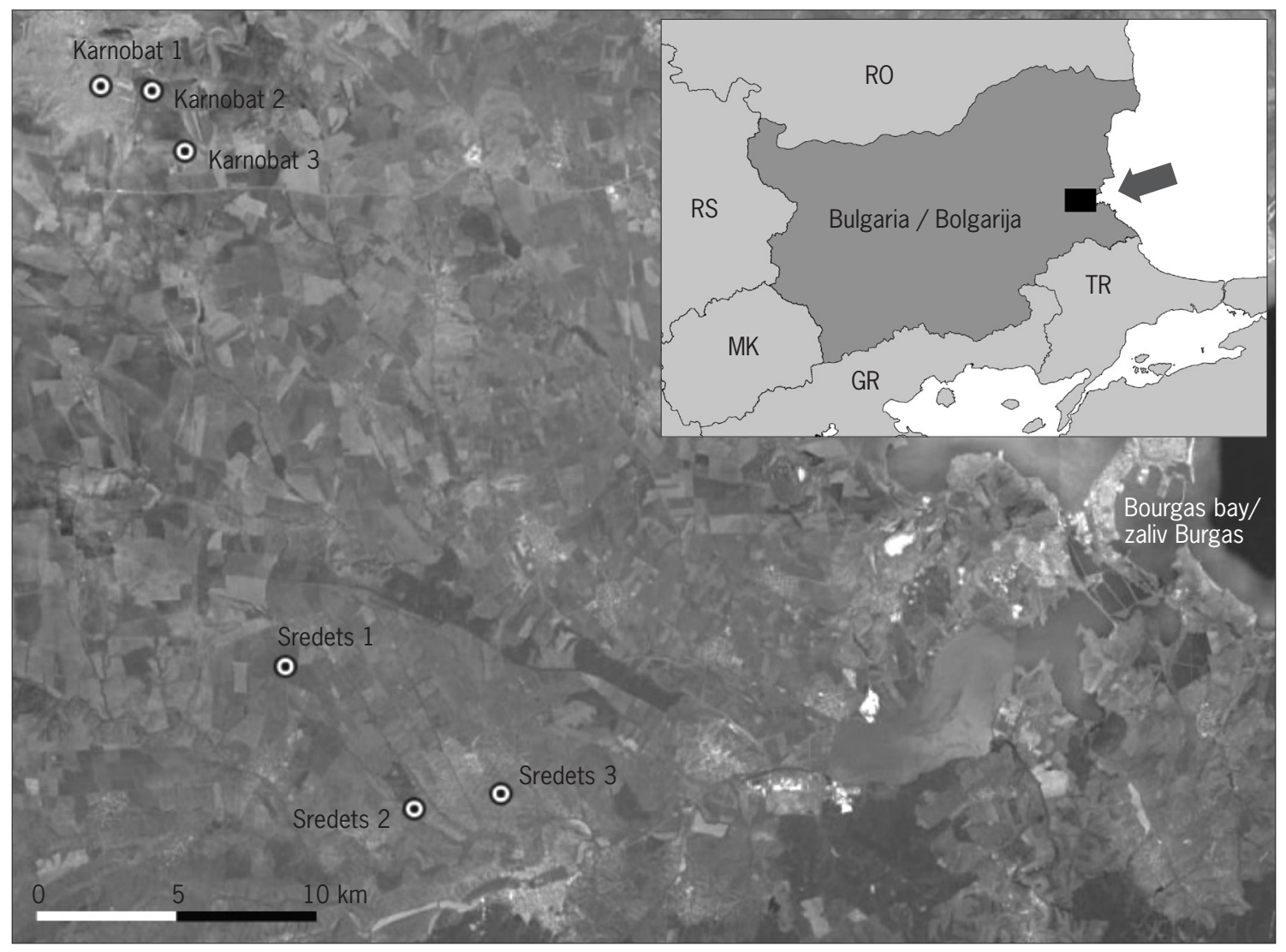

Figure 1: Study area in Bourgas district, SE Bulgaria, with locations of the six observation points depicted. Satellite image is courtesy of Google Earth, Google Inc., Mountain View, CA.

Slika 1: Območje preučevanja v okrožju Bourgas, JV Bolgarija, s prikazanimi lokacijami šestih opazovalnih točk. Objavo satelitske slike nam je omogočil Google Earth, Google Inc., Mountain View, CA.

observation areas, wind farms with ca. 20 turbines are planned, which was the reason for choosing them for the present study. The terrain in the two areas is hilly with gentle slopes, while predominant vegetation types are different grassland habitats - meadows, steppe, stony steppe and agricultural fields. In Sredets area, especially close to the point Sredets 2 , there is also an oak forest, with surface area of ca. 120 ha. The average altitude of the terrain at Sredets area is 108 $\mathrm{m}$ a.s.l., while Karnobat area is situated on average at $310 \mathrm{~m}$ a.s.l. Coordinates of the observation points are as follows: Sredets 1, 42.42724 N, 27.07012 E (155 m a.s.l.); Sredets 2, $42.37752 \mathrm{~N}, 27.12667 \mathrm{E}$ (76 m a.s.l.); Sredets 3, 42.38200 N, 27.16603 E (94 m a.s.l.); Karnobat 1, 42.62620 N, 26.99345 E (321 m a.s.l.); Karnobat 2, 42.62422 N, 27.01656 E (335 m a.s.l.); Karnobat 3, 42.60352 N, 27.03060 E (273 $\mathrm{m}$ a.s.l.). In all figures and tables, these are presented in order from the west to the east, Karnobat 1 being the westernmost and Sredets 3 the easternmost observation point. Distance between Sredets and Karnobat observation areas is ca. $21 \mathrm{~km}$ in SE-NW direction. Distance from the Black Sea to the closest Sredets point is $24.5 \mathrm{~km}$, and $37.3 \mathrm{~km}$ to the closest Karnobat point.

At each observation point, we conducted simultaneous counts of all diurnal migratory birds for 15 days of the spring migration season of 2008, divided in three 5-day periods (counting sessions), representing three months of the corresponding migration season - the first in March $\left(27^{\text {th }}-31^{\text {st }}\right)$, the second in April $\left(20^{\text {th }}-24^{\text {th }}\right)$ and the third in May $\left(12^{\text {th }}-16^{\text {th }}\right)$. We chose these three periods with the aim to obtain a representative sample for the whole spring migration period. However, here we present only data on the migration of the soaring migrants storks, pelicans, raptors and cranes. Furthermore, we include herein Bee-eater Merops apiaster, as migrant 
Table 1: Numbers of all soaring migratory birds counted in three 5-day periods during spring migration period at observation points, distributed over two separate areas (Karnobat and Sredets, respectively) in SE Bulgaria.

Tabela 1: Število vseh jadrajočih ptic, selečih se nad dvema ločenima območjema (Karnobat in Sredets) v JV Bolgariji, preštetih $v$ treh petdnevnih obdobjih med spomladansko selitvijo z opazovalnih točk.

\begin{tabular}{|c|c|c|c|c|c|c|c|c|c|}
\hline Species / Vrsta & $\begin{array}{c}\text { Karnobat } \\
1\end{array}$ & $\begin{array}{c}\text { Karnobat } \\
2\end{array}$ & $\begin{array}{c}\text { Karnobat } \\
3\end{array}$ & $\begin{array}{c}\text { Karnobat } \\
\text { total/ } \\
\text { skupaj }\end{array}$ & Sredets 1 & Sredets 2 & Sredets 3 & $\begin{array}{l}\text { Sredets } \\
\text { total/ } \\
\text { skupaj }\end{array}$ & $\begin{array}{c}\text { Total } \\
\text { overall/ } \\
\text { Skupaj } \\
\text { vse }\end{array}$ \\
\hline Ciconia ciconia & 5,527 & 5,745 & 6,145 & $\mathrm{I} 7,4 \mathrm{I} 7$ & $\mathrm{I}, 697$ & $\mathrm{I}, 894$ & 2,350 & $5,94 \mathrm{I}$ & 23,358 \\
\hline Aquila pomarina & 440 & 683 & 807 & $\mathrm{I}, 930$ & 218 & 405 & 559 & $\mathrm{I}, \mathrm{I} 82$ & $3, \mathrm{II} 2$ \\
\hline Merops apiaster & $3 I$ & 155 & I 22 & 308 & 346 & 258 & 307 & 9II & I, 219 \\
\hline Buteo buteo & I3 I & I 2 I & 156 & 408 & I 13 & 83 & 247 & 443 & $85 \mathrm{I}$ \\
\hline Ciconia nigra & $8 \mathrm{I}$ & I 72 & 83 & 336 & 196 & 93 & 64 & 353 & 689 \\
\hline Pernis apivorus & 53 & I 40 & I7 I & 364 & $3 \mathrm{I}$ & 62 & 44 & I37 & 501 \\
\hline Pelecanus onocrotalus & & 8 & 8 & I6 & 50 & 150 & I 45 & 345 & $36 I$ \\
\hline Accipiter nisus & 24 & 25 & 26 & 75 & 25 & 17 & 65 & 107 & 182 \\
\hline Circus aeruginosus & I7 & 23 & 22 & 62 & 47 & I6 & IO & 73 & I35 \\
\hline Circaetus gallicus & IO & 6 & 19 & 35 & 23 & I9 & 20 & 62 & 97 \\
\hline Falco vespertinus & 29 & IO & 15 & 54 & 8 & 9 & 26 & 43 & 97 \\
\hline Circus pygargus & 8 & IO & I3 & $3 \mathrm{I}$ & II & I3 & 5 & 29 & 60 \\
\hline Hieraetus pennatus & I 2 & 3 & 5 & 20 & 7 & II & I6 & 34 & 54 \\
\hline Milvus migrans & I 2 & 5 & 5 & 22 & 4 & 9 & I 4 & 27 & 49 \\
\hline Falco tinnunculus & II & 3 & 2 & I6 & 2 & 8 & II & $2 \mathrm{I}$ & 37 \\
\hline Buteo rufinus & 7 & 2 & 7 & I6 & & II & 3 & I 4 & 30 \\
\hline Accipiter gentilis & I & 4 & 7 & I 2 & 7 & 4 & 2 & I3 & 25 \\
\hline Aquila heliaca & 3 & 4 & 5 & $\mathrm{I} 2$ & & 4 & 6 & IO & 22 \\
\hline Circus cyaneus & & 4 & & 4 & I 2 & I & & 13 & 17 \\
\hline Circus macrourus & 2 & 3 & I & 6 & 7 & I & & 8 & I4 \\
\hline Pandion haliaetus & & I & & I & 3 & 2 & 2 & 7 & 8 \\
\hline Falco subbuteo & 2 & 2 & & 4 & & 2 & 2 & 4 & 8 \\
\hline Falco peregrinus & 2 & & & 2 & I & 2 & 2 & 5 & 7 \\
\hline Aquila chrysaetos & I & 2 & I & 4 & & & & & 4 \\
\hline Haliaeetus albicilla & & I & & I & I & & & I & 2 \\
\hline Neophron percnopterus & & 2 & & 2 & & & & & 2 \\
\hline Accipiter brevipes & I & & I & 2 & & & & & 2 \\
\hline Circus sp. & & & 7 & 7 & 3 & & & 3 & IO \\
\hline C. pygargus / macrourus & I & & & I & 2 & 2 & & 4 & 5 \\
\hline B. buteo / P. apivorus & & & & & & 3 & & 3 & 3 \\
\hline $\begin{array}{l}\text { Unidentified raptors/ } \\
\text { Nedoločene ujede }\end{array}$ & & 24 & 39 & 63 & I6 & 8 & I & 25 & 88 \\
\hline Total / Skupaj & 6,406 & 7,158 & 7,667 & $2 \mathrm{I}, 23 \mathrm{I}$ & 2,830 & 3,087 & $3,90 \mathrm{I}$ & $9,8 \mathrm{I} 8$ & 31,049 \\
\hline
\end{tabular}

flocks favour thermal conditions and some tendency to concentrate at narrow Mediterranean crossings has been observed at this species, too (Cramp 1985). However, this species was omitted from most analyses as our study was mainly focused on large soaring migrants.

Observations started at $9.00 \mathrm{~h}$ and continued until $18.00 \mathrm{~h}$ (astronomical / winter time), but yet small numbers of migrants were recorded outside this time frame. We use three time clusters to compare the migration intensity during the day - between 9.00 and 12.00 hrs (morning), between 12.00 and 15.00 hrs (early afternoon) and between 15.00 and 18.00 hrs (late afternoon). For each observed migrating individual or flock we determined flight altitude and flight direction. Altitude was estimated using field markers for which we had information on their height, i.e. wind measuring pylons, pylons of GSM 


\section{Ciconia ciconia}
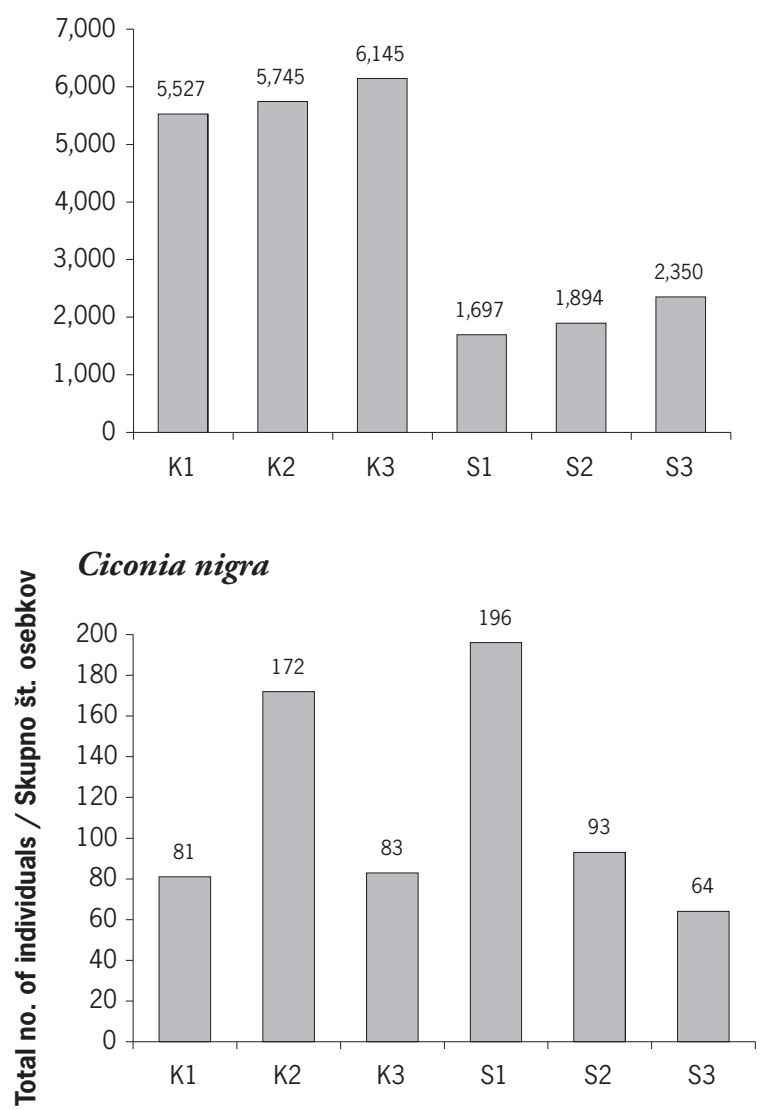

Pernis apivorus

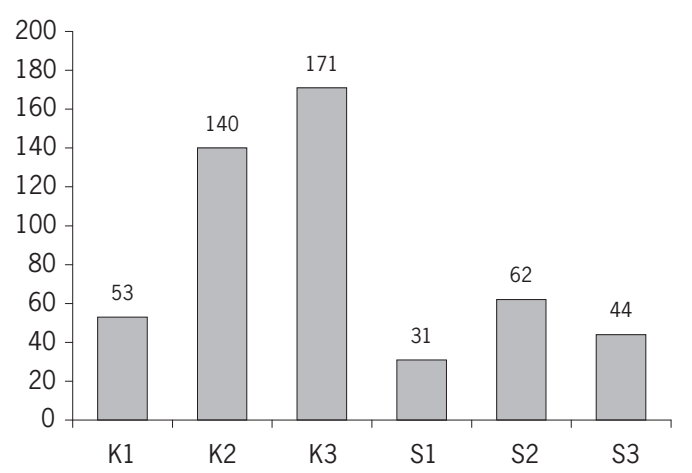

\section{Aquila pomarina}

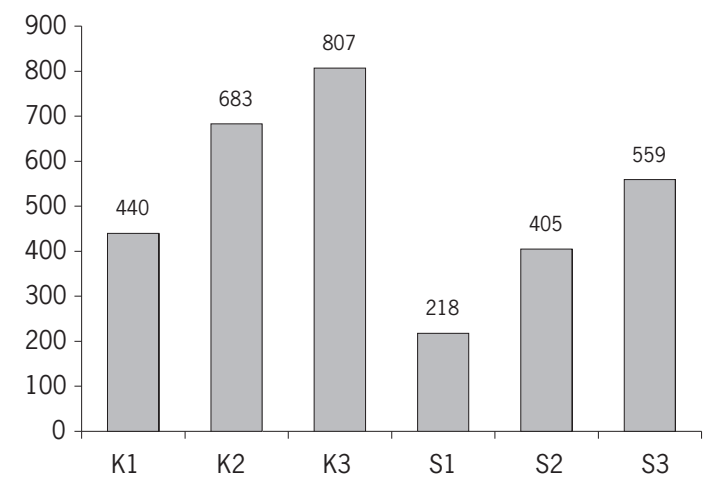

Buteo buteo

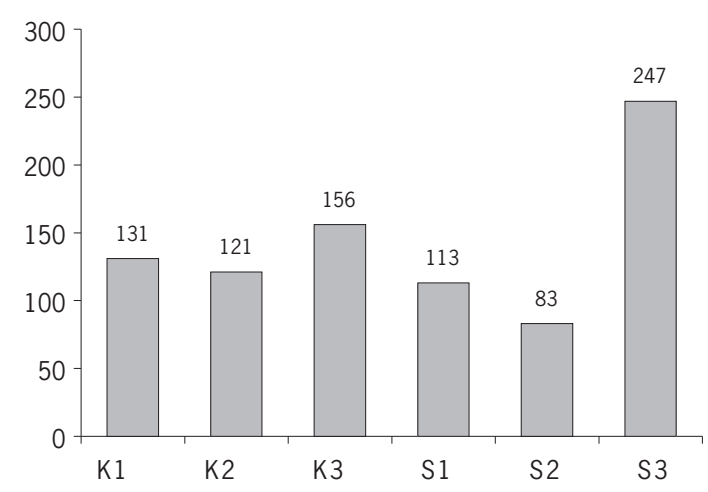

Total / Skupaj

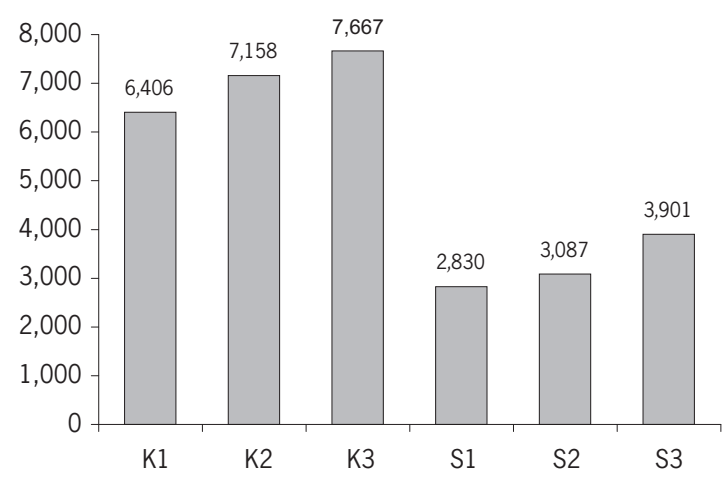

Observation point / Opazovalna točka

Figure 2: Total numbers of five most numerous, large soaring migratory birds and all counted soaring migrants at observation points, distributed over two separate areas (Karnobat and Sredets, respectively) in SE Bulgaria.

Slika 2: Skupno število petih najštevilčnejših velikih jadrajočih selečih se ptic in vseh jadrajočih selivk, preštetih z opazovalnih točk v območjih Karnobat in Sredets v JV Bolgariji. 


\section{Ciconia ciconia}

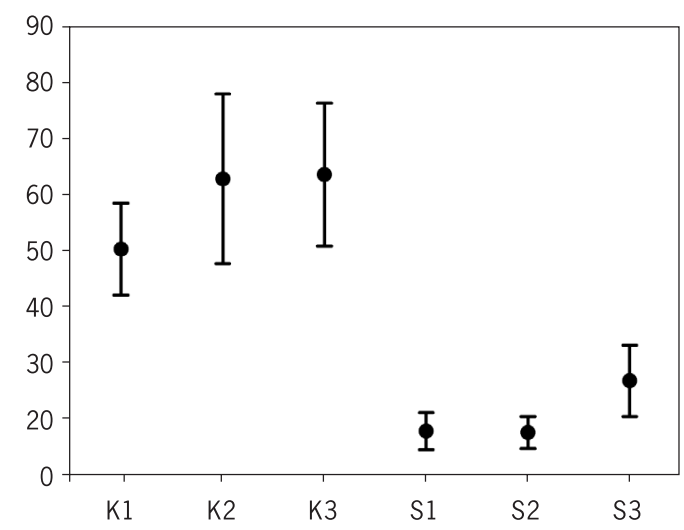

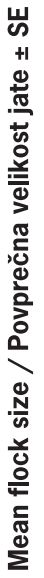

\section{Ciconia nigra}

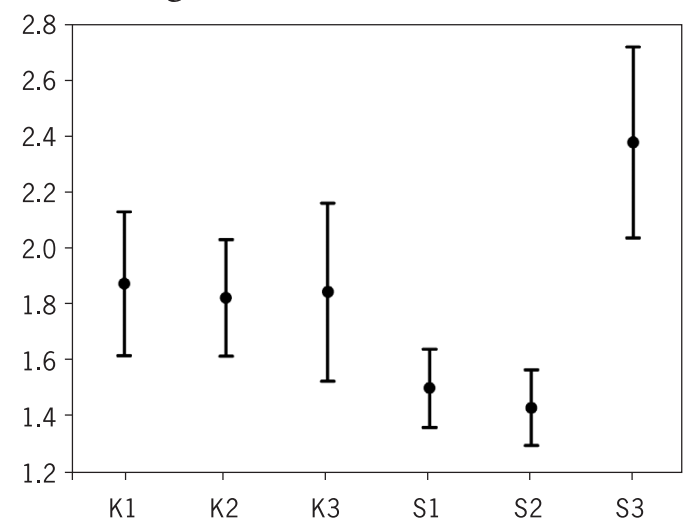

Aquila pomarina

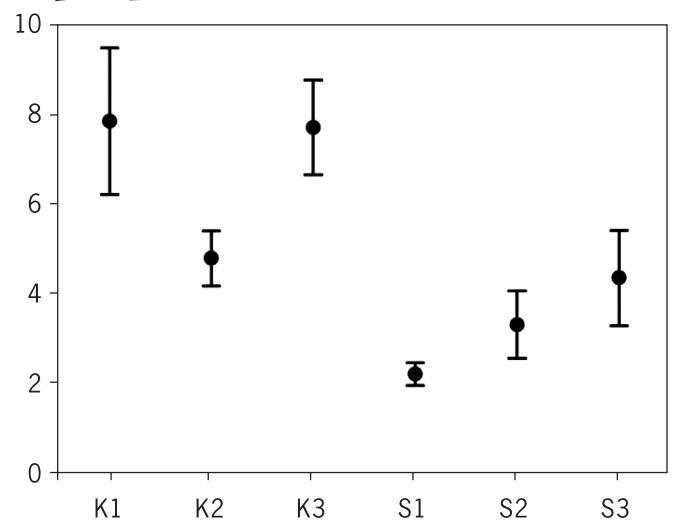

Buteo buteo

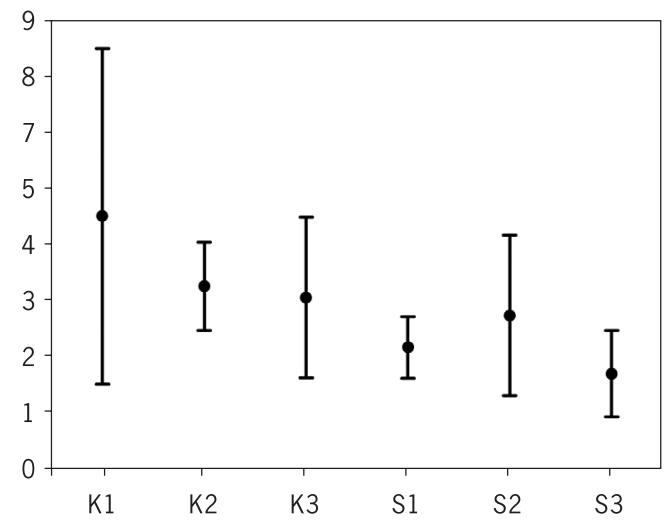

Pernis apivorus

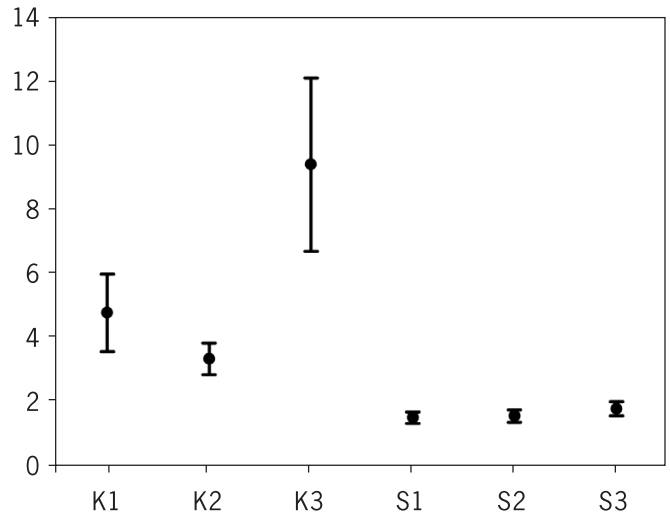

Observation point / Opazovalna točka

Figure 3: Mean flock size $( \pm S E$ ) of five most numerous, large soaring migratory birds at observation points, distributed over two separate areas (Karnobat and Sredets, respectively) in SE Bulgaria.

Slika 3: Povprečna velikost jate $( \pm S E)$ petih najštevilčnejših velikih jadrajočih selečih se ptic nad opazovalnimi točkami v območjih Karnobat in Sredets v JV Bolgariji. 
transmission and electricity pylons. In our choice of the observation points, the presence of such structures was considered an important detail. We used predetermined altitude classes of 0-20 m, 20-40 m, 40$60 \mathrm{~m}, 60-80 \mathrm{~m}, 80-100 \mathrm{~m}, 100-150 \mathrm{~m}, 150-200$ $\mathrm{m}, 200-250 \mathrm{~m}, 250-300 \mathrm{~m}, 300-500 \mathrm{~m}$ and $>500$ $\mathrm{m}$ for estimation. Flight directions (N, S, E, W, NE, NW, SE \& SW) were determined using GPS device (Garmin GPS 60). The weather conditions during our counts were favourable for migration and its registering. In almost all days the weather was sunny, clear, with light or moderate winds.

Analyses were done through generalized linear models (GLM) with negative binomial distribution when influence of different factors on flock size and flight altitude was examined. Month (5-day period), observation area and observation point within the area were used as factors, while time cluster was entered as a covariate. Statistical analyses were performed with IBM SPSS Statistics 19.

\section{Results}

\subsection{Migrant numbers, their spatial and temporal distribution, and influence of factors on migration}

In total, we detected 31,049 soaring birds of at least 27 species passing over six observation points during 15 counting days. In Karnobat area, situated farther from the Black Sea coast, the total mean number $( \pm$ SD) of birds migrating over observation points was two-fold higher than in Sredets area - 7,077 $( \pm 634)$ vs. 3,273 $( \pm 559)$. The numbers of birds counted varied from 2,830 and 7,667 between the observation points, being lowest at Sredets 1 point and highest at Karnobat 3 point (Table 1, Figure 2). Thus, the hypothesis of a reduction in migrant numbers with increasing distance from the coast was not confirmed by our results.

Overall, there was a significant difference in flock size and flight altitude within separate observation area (i.e. among observation points) as well as between the two observation areas (Karnobat vs. Sredets areas) and the three 5-day periods. However, there was a substantial variance in factors significantly affecting the flock size and flight altitude among most numerous individual species (Table 2). In general, the flock size of migrants corresponded to the overall numbers at separate observation points, but with a few noticeable exceptions (Figures $2 \& 3$ ). Time cluster had a significant influence only on flight altitude of two most numerous migrants, but did by no means influence the flock size.
The totals of counted individuals at each observation point are compared for the five most numerous, large migrants and for all counted soaring birds in Figure 2. Separate 5-day period numbers for these species and overall numbers for all species are given in Table 3 . Further, we present the results for these five species separately:

\section{(1) White Stork Ciconia ciconia}

Numbers of this abundant species determine to a high extent the overall numbers of counted soaring birds. Numbers counted in Karnobat area $(17,417)$ are almost three times higher than those in Sredets area $(5,941)$. Within each observation area there were no significant differences in flock size between separate points, but among the two observation areas the average flock size differed significantly, being higher in Karnobat area (Table 2, Figure 3). While time cluster had no influence on the flock size, the 5-day period showed a significant effect. The highest numbers $(9,028$ overall, $38.7 \%)$ were counted during 5 -day period in March, but the numbers from April $(8,239,35.3 \%)$ are just somewhat lower (Table 3). Interestingly, at observation points Sredets 1 and Sredets 2 the highest numbers were counted during the May counting session. Flight altitude was significantly influenced by all studied effects. The effects of observation area, 5-day period, time cluster and observation point within area on White Stork flock size and flight altitude are shown in Table 2.

\section{(2) Lesser Spotted Eagle Aquila pomarina}

Lesser Spotted Eagle was the second most numerous migrant observed during the study. Observation area, observation point within area and time cluster showed significant effect on the flock size (Table 2). Similarly to the White Stork, the migration had much higher intensity in Karnobat area compared to Sredets area $(1,930$ vs. 1,182$)$. In both study areas, numbers decreased notably from the east to the west (Figure 2), but the average flock size at the westernmost observation point in Karnobat area was higher compared to the neighbouring point Karnobat 2 and similar to the value of Karnobat 3 observation point (Figure 3). Flight altitude of Lesser Spotted Eagles was significantly influenced by observation area (lower in Sredets area) and time cluster (Table 2 ). The migration was distinctively concentrated in March (2,863 overall, 92\%) (Table 3). 
Table 2: $P$ values from generalized linear models, analyzing influence of different factors on (a) flock size and (b) flight altitude of the 10 most numerous, large soaring migratory birds and all counted soaring migrants in SE Bulgaria. Considered factors are 5-day period (month) of the study, time cluster, observation area (Karnobat or Sredets) and observation point (Karnobat 1, $2 \& 3$ and Sredets 1, $2 \& 3$ ) within a separate area. Significant influences $(P<0.05)$ are denoted in bold.

Tabela 2: Vrednosti $P$ posplošenih linearnih modelov, z razčlenitvijo vpliva različnih dejavnikov na (a) velikost jate in (b) višino leta desetih najštevilčnejših velikih jadrajočih selečih se ptic in vseh preštetih jadrajočih selivk v JV Bolgariji. Upoštevani dejavniki so petdnevno obdobje (mesec) preučevanja, časovno obdobje, območje opazovanja (Karnobat ali Sredets) in opazovalne točke (Karnobat 1, 2, 3 in Sredets 1, 2, 3) znotraj posameznega območja. Pomembni vplivi $(P<0,05)$ so prikazani v mastnem tisku.

a)

\begin{tabular}{|c|c|c|c|c|}
\hline Species / Vrsta & $\begin{array}{c}\text { 5-day period } \\
\text { (month)/ } \\
\text { Pentada (mesec) }\end{array}$ & $\begin{array}{l}\text { Time cluster/ } \\
\text { Časovno obdobje }\end{array}$ & $\begin{array}{l}\text { Observation area/ } \\
\text { Območje opazovanja }\end{array}$ & $\begin{array}{l}\text { Observation point/ } \\
\text { Opazovalna točka }\end{array}$ \\
\hline Ciconia ciconia & $<0.001$ & $0.09 \mathrm{I}$ & $<0.001$ & 0.079 \\
\hline Aquila pomarina & $<0.001$ & 0.056 & $<0.001$ & 0.001 \\
\hline Buteo buteo & 0.396 & O.I 45 & $0.89 \mathrm{I}$ & 0.152 \\
\hline Ciconia nigra & $<0.001$ & 0.539 & 0.176 & 0.743 \\
\hline Pernis apivorus & 0.064 & $0.47 \mathrm{I}$ & $<0.001$ & 0.043 \\
\hline Pelecanus onocrotalus & $0.08 \mathrm{I}$ & 0.539 & 0.035 & 0.905 \\
\hline Accipiter nisus & 0.952 & 0.872 & 0.652 & 0.926 \\
\hline Circus aeruginosus & 0.873 & 0.770 & 0.688 & 0.948 \\
\hline Circaetus gallicus & 0.894 & 0.993 & $0.96 \mathrm{I}$ & 0.988 \\
\hline Falco vespertinus & $0.40 \mathrm{I}$ & 0.673 & 0.389 & 0.073 \\
\hline Total / Skupaj & 0.006 & 0.315 & $<0.001$ & 0.031 \\
\hline
\end{tabular}

b)

\begin{tabular}{|c|c|c|c|c|}
\hline Species / Vrsta & $\begin{array}{c}\text { 5-day period } \\
\text { (month)/ } \\
\text { Pentada (mesec) }\end{array}$ & $\begin{array}{l}\text { Time cluster/ } \\
\text { Časovno obdobje }\end{array}$ & $\begin{array}{c}\text { Observation area/ } \\
\text { Območje opazovanja }\end{array}$ & $\begin{array}{l}\text { Observation point } \\
\text { Opazovalna točka }\end{array}$ \\
\hline Ciconia ciconia & 0.014 & $<0.001$ & $<0.001$ & 0.012 \\
\hline Aquila pomarina & 0.700 & 0.032 & $<0.001$ & 0.120 \\
\hline Buteo buteo & 0.039 & $0.28 \mathrm{I}$ & 0.009 & 0.162 \\
\hline Ciconia nigra & 0.062 & 0.553 & $<0.001$ & 0.157 \\
\hline Pernis apivorus & 0.426 & 0.939 & 0.176 & 0.092 \\
\hline Pelecanus onocrotalus & 0.673 & 0.335 & 0.713 & 0.103 \\
\hline Accipiter nisus & 0.157 & 0.983 & 0.102 & 0.005 \\
\hline Circus aeruginosus & 0.085 & 0.486 & 0.057 & 0.486 \\
\hline Circaetus gallicus & 0.224 & 0.650 & 0.020 & $0.3 \mathrm{I} 2$ \\
\hline Falco vespertinus & 0.528 & $0.97 \mathrm{I}$ & 0.713 & O.I $4 \mathrm{I}$ \\
\hline Total / Skupaj & $<0.001$ & 0.006 & $<0.001$ & 0.001 \\
\hline
\end{tabular}

\section{(3) Common Buzzard Buteo buteo}

It was a common and rather equally distributed migrant over the studied territory. Migration was registered mainly in March (333 overall, 39.2\%) and April (441 overall, 51.8\%) (Table 3). In contrast to the majority of other most numerous species, the highest numbers and the largest flock size were registered at the closest observation point to the Black Sea - Sredets 3 (Figure 2). No significant influence of the studied effects on flock size could be identified (Table 2), while 5-day period and observation area had a significant effect on flight altitude of Common Buzzards.

\section{(4) Black Stork Ciconia nigra}

Migration pattern shown by the migrating Black Storks (Figure 2) was completely different from that of White Stork. The highest number (196) was observed at the westernmost observation point of Sredets area (Sredets 1). A trend of increasing 
Table 3: Numbers and percentage of five most numerous, large soaring migratory birds and all counted soaring migrants over Karnobat and Sredets observation areas in SE Bulgaria, in 5-day periods, representing three months of the spring migration season.

Tabela 3: Število in odstotek petih najštevilčnejših velikih jadrajočih selečih se ptic in vseh preštetih jadrajočih ptic, ki se selijo prek opazovalnih območij Karnobat in Sredets v JV Bolgariji v petdnevnih obdobjih med tremi meseci spomladanske selitvene sezone.

\begin{tabular}{|c|c|c|c|c|c|c|}
\hline \multirow{2}{*}{ Species / Vrsta } & \multicolumn{2}{|c|}{ March / Marec } & \multicolumn{2}{|c|}{ April } & \multicolumn{2}{|c|}{ May / Maj } \\
\hline & No. / Št. & $\%$ & No. / Št. & $\%$ & No. / Št. & $\%$ \\
\hline Ciconia ciconia & 9,028 & 38.7 & 8,239 & $35 \cdot 3$ & $6,09 \mathrm{I}$ & 26.I \\
\hline Aquila pomarina & 2,863 & 92.0 & I6I & 5.2 & 88 & 2.8 \\
\hline Buteo buteo & 333 & 39.1 & $44 \mathrm{I}$ & 51.8 & 77 & 9.0 \\
\hline Ciconia nigra & 406 & 58.9 & 215 & $3 \mathrm{I} .2$ & 68 & 9.9 \\
\hline Pernis apivorus & & 0.0 & 39 & 7.8 & 462 & 92.2 \\
\hline Vse vrste / All species & I3,207 & 44.3 & 9,586 & 32.1 & 7,037 & 23.6 \\
\hline
\end{tabular}

numbers from the east to the west was detected in Sredets area, but the flock size was generally small and thus the differences among observation points were not significant (Table 2). In Karnobat area, no such trend was detected, but numbers were similar to those at Sredets. Flock size differed significantly among the three 5-day periods, but no significant influence of other studied effects could be confirmed (Table 2). The average flight altitude was similar as in other most numerous soaring migrants significantly influenced by the observation area. At all points except Sredets 3, the highest numbers of migrating Black Storks were counted in March. This was also the overall peak month of Black Stork migration with a total of 406 individuals (58.9\%) (Table 3).

\section{(5) Honey Buzzard Pernis apivorus}

Intensive migration of this species was registered in May (total 462 overall, 92.2\%) (Table 4). The migration was much more intensive in the Karnobat observation area (Figure 2), where we observed a significant reduction of migration intensity from the east to the west (Table 2). Average flock size was also significantly larger at Karnobat compared to Sredets area, whereas within Karnobat area it was much larger at Karnobat 3 compared to both other points (Figure 3). Flight altitude of Honey Buzzards was not influenced significantly by any of the effects studied.

Among the registered species migrating over the study area, some rare and threatened soaring bird species were observed, such as Imperial Eagle Aquila heliaca (in both observation areas), Egyptian Vulture
Neophron percnopterus (only in Karnobat area), Pallid Harrier Circus macrourus (in both observation areas) and White-tailed Eagle Haliaeetus albicilla (in both observation areas). White Pelican Pelecanus onocrotalus was registered more regularly in Sredets area with 345 individuals in total, while at Karnobat area only 16 pelicans were counted.

\subsection{Flight altitude}

The average flight altitude calculated for all counted migrating soaring birds $( \pm$ SE) varied between 116.6 $\pm 6.24 \mathrm{~m}$ and $242.4 \pm 9.20 \mathrm{~m}$ among the different observation points. Overall, flight altitude depended on both observation area and specific observation point as well as on time cluster and the 5-day observation periods (Table 2). In general, birds passed at much higher altitude above Karnobat area (mean flight altitude $208.3 \mathrm{~m} \pm 6.4$ ) compared to Sredets area (mean flight altitude $130.5 \mathrm{~m} \pm 4.4$ ). This is true for nine out of 10 most numerous migrating species, well represented in both observation areas (Figure 4). However, only for White Stork, Lesser Spotted Eagle, Common Buzzard, Black Stork and Short-toed Eagle Circaetus gallicus the influence of observation area on flight altitude was significant (Table 2). Among all, the flight altitude was lowest for Bee-eater and Redfooted Falcon Falco vespertinus compared to all other analyzed species. White Stork was among the species passing at the highest altitude. All large soaring birds, except Marsh Harrier C. aeruginosus in Sredets area, migrated at average flight altitude of more than 100 $\mathrm{m}$ (Figure 4). 


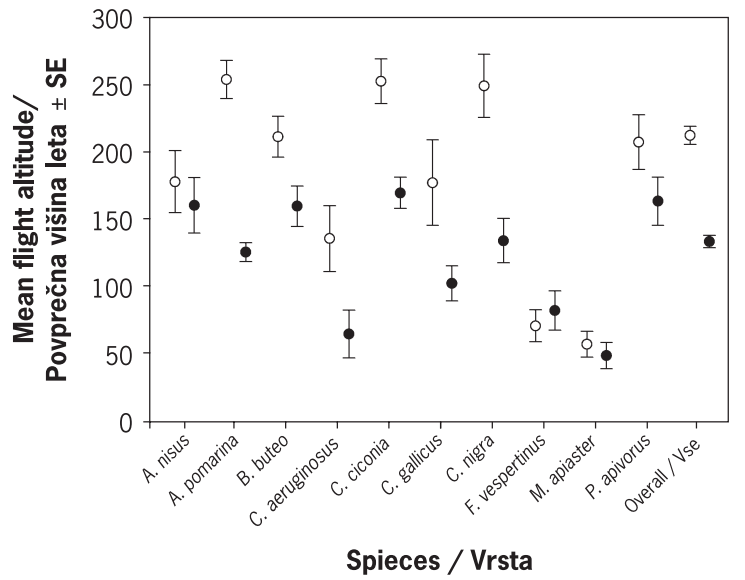

Figure 4: Mean flight altitude ( \pm SE) of the most numerous soaring migratory birds, well represented in both observation areas, over the Karnobat (filled circles) and Sredets observation areas (empty circles) in SE Bulgaria.

Slika 4: Povprečna višina leta ( \pm SE) najštevilčnejših jadrajočih selečih se ptic, ki so dobro zastopane v obeh opazovalnih območjih, in sicer nad Karnobatom (polni krožci) in Sredetsom (prazni krožci) v JV Bolgariji.

\subsection{Direction of migration}

In both observation areas, northern direction was the most commonly observed flight direction $(46.3 \%$ of all recorded flight directions), but the NW direction was much better presented in Karnobat area compared to Sredets area $(25.7 \%$ vs. $20.0 \%)$. At the observation point Karnobat 3, NW direction even prevailed (NW direction 44.1\%, northern direction $29.9 \%$ of all recorded flight directions). Flight directions of all recorded soaring birds observed in Sredets and Karnobat areas are presented in Figure 5.

\subsection{Daily timing of migration}

The highest numbers of soaring migrants passed in the late afternoon, between 15.00 and 18.00 hrs 11,554 individuals, i.e. $43.0 \%$ of all counted birds in the observation period. During the morning time cluster, between 9.00 and $12.00 \mathrm{hrs}$, we counted 8,838 birds (32.9\%), while during the early afternoon time cluster, between 12.00 and 15.00 hrs, 6,488 individuals $(24.1 \%)$ were counted.

White Stork showed uniform daily timing of migration in Sredets area, but in Karnobat area the majority $(48.1 \%)$ of all birds passed during the late afternoon. Even larger differences between the two observation areas in daily timing of migration were registered for Lesser Spotted Eagle and Common Buzzard. In Sredets area, both species had a clear maximum of their migration in the early afternoon time cluster. In Karnobat area, Lesser Spotted Eagle and Common Buzzard showed maximal migration intensity during the morning hours and the late
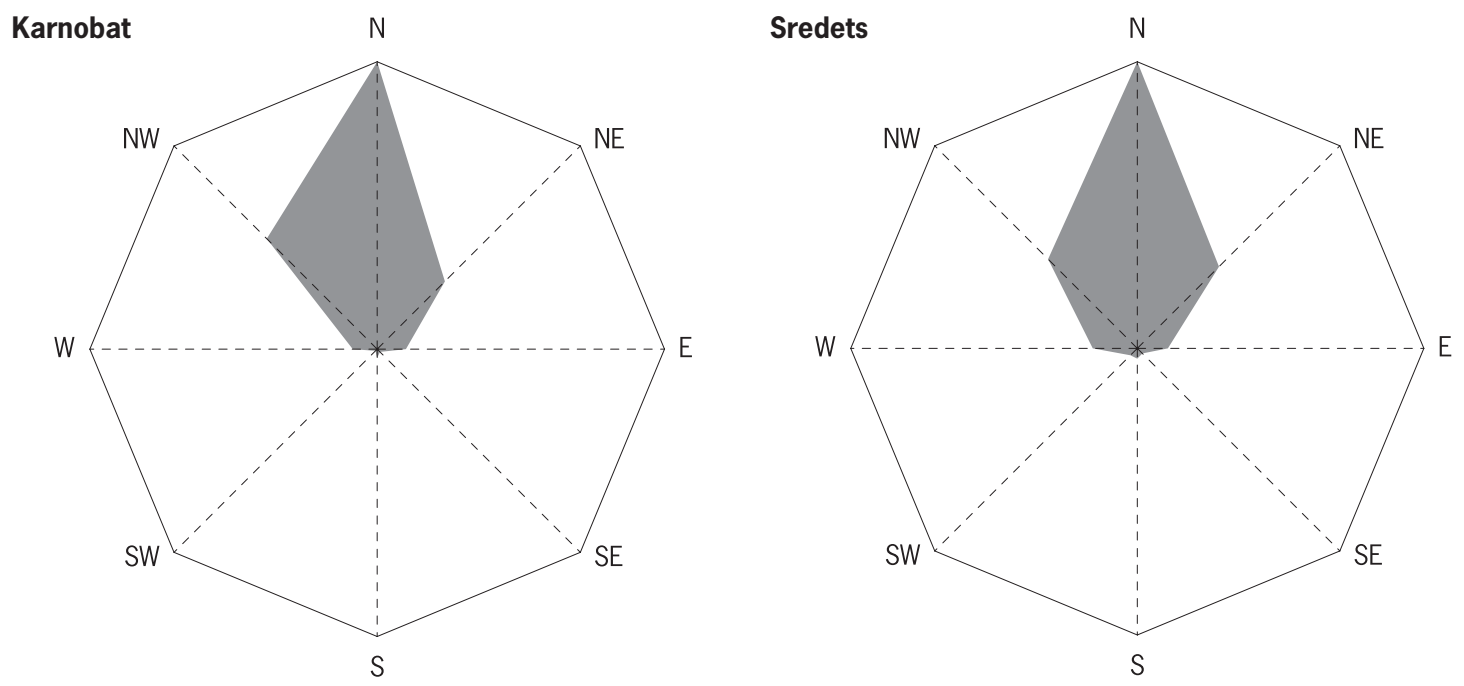

Figure 5: Flight directions of soaring migratory birds over Karnobat and Sredets observation areas, given as proportions of solitary birds or flocks flying in particular direction.

Slika 5: Smeri leta jadrajočih selečih se ptic nad območjema opazovanja Karnobat in Sredets, prikazane kot deleži posameznih ptic ali jat, letečih v določeni smeri. 
Table 4: Daily timing of migration of five most numerous, large soaring migratory birds and all counted soaring migrants over Karnobat and Sredets observation areas in SE Bulgaria, given as number and percentage of individuals in three time clusters (morning, early afternoon and late afternoon, respectively).

Tabela 4: Dnevni čas selitve petih najštevilčnejših velikih jadrajočih selečih se ptic in vseh preštetih jadrajočih selivk nad opazovalnimi območji Karnobat in Sredets v JV Bolgariji, prikazan kot število in odstotek osebkov v treh časovnih obdobjih (jutro, zgodaj popoldne oz. pozno popoldne).

\begin{tabular}{|c|c|c|c|c|c|c|c|}
\hline \multirow{2}{*}{ Species / Vrsta } & \multirow{2}{*}{$\begin{array}{c}\text { Time cluster/ } \\
\text { Časovno } \\
\text { obdobje (h) }\end{array}$} & \multicolumn{2}{|c|}{ Karnobat } & \multicolumn{2}{|c|}{ Sredets } & \multicolumn{2}{|c|}{ Total / Skupaj } \\
\hline & & No. / Št. & $\%$ & No. / Št. & $\%$ & No. / Št. & $\%$ \\
\hline \multirow{3}{*}{$\begin{array}{l}\text { Ciconia ciconia } \\
(\mathrm{n}=2 \mathrm{I}, 005)\end{array}$} & $9.00-12.00$ & 5,563 & 34.5 & I,739 & 36.0 & 7,302 & 34.8 \\
\hline & $\mathrm{I} 2.00-\mathrm{I} 5.00$ & 2,767 & 17.3 & $\mathrm{I}, 540$ & 30.1 & 4,307 & 20.5 \\
\hline & $15.00-18.00$ & 7,705 & $48 . \mathrm{I}$ & $\mathrm{I}, 69 \mathrm{I}$ & 34.0 & 9,396 & 44.7 \\
\hline \multirow{3}{*}{$\begin{array}{l}\text { Aquila pomarina } \\
(\mathrm{n}=2,4 \mathrm{I} 5)\end{array}$} & $9.00-\mathrm{I} 2.00$ & 852 & 56.2 & I 25 & 13.9 & 977 & 40.5 \\
\hline & I2.00-I5.0O & 294 & I9.4 & 623 & 69.2 & 917 & 38.0 \\
\hline & I5.00-I8.00 & 369 & 24.4 & 152 & I6.9 & 521 & 21.6 \\
\hline \multirow{3}{*}{$\begin{array}{l}\text { Buteo buteo } \\
(\mathrm{n}=562)\end{array}$} & $9.00-\mathrm{I} 2.00$ & 58 & $23 . \mathrm{I}$ & 64 & 20.6 & $\mathrm{I} 22$ & 21.7 \\
\hline & I2.00-I5.0O & $4 \mathrm{I}$ & I6.3 & I 32 & 42.4 & $\mathrm{I} 73$ & 30.8 \\
\hline & $15.00-18.00$ & 152 & 60.6 & II 5 & 37.0 & 267 & 47.5 \\
\hline \multirow{3}{*}{$\begin{array}{l}\text { Ciconia nigra } \\
(\mathrm{n}=572)\end{array}$} & $9.00-\mathrm{I} 2.00$ & I 24 & 46.8 & I 22 & 39.7 & 246 & 43.0 \\
\hline & $\mathrm{I} 2.00-\mathrm{I} 5.00$ & 53 & 20.0 & 104 & 33.9 & 157 & $27 \cdot 4$ \\
\hline & I5.00-I8.00 & 88 & 33.2 & $8 \mathrm{I}$ & 26.4 & 169 & 29.5 \\
\hline \multirow{3}{*}{$\begin{array}{l}\text { Pernis apivorus } \\
(\mathrm{n}=4 \mathrm{II})\end{array}$} & $9.00-\mathrm{I} 2.00$ & 46 & I 5.3 & 30 & 27.0 & 76 & I 8.5 \\
\hline & I2.00-I5.0O & IOO & $33 \cdot 3$ & 38 & 34.2 & I3 8 & 33.6 \\
\hline & I5.00-I8.00 & I54 & 51.3 & 43 & 38.7 & I97 & $47 \cdot 9$ \\
\hline \multirow{3}{*}{$\begin{array}{l}\text { Overall / Skupaj } \\
(\mathrm{n}=26,880)\end{array}$} & $9.00-\mathrm{I} 2.00$ & 6,470 & 34.5 & 2,368 & 29.2 & 8,838 & 32.9 \\
\hline & $\mathrm{I} 2.00-15.00$ & 3,532 & I8.8 & 2,956 & 36.4 & 6,488 & $24 \cdot I$ \\
\hline & I5.00-I8.00 & $8,76 \mathrm{I}$ & 46.7 & 2,793 & 34.4 & II, 554 & 43.0 \\
\hline
\end{tabular}

afternoon, respectively. Daily timing of Black Stork migration in Karnobat was quite similar to the pattern characteristic of Lesser Spotted Eagle with prevailing numbers during the morning hours. In Sredets area, Black Stork showed slight trend for decreasing migration intensity during the day. The comparison of daily timing of migration for the five most numerous species between the two studied areas is presented in Table 4.

\section{Discussion}

We found intensive daytime spring migration of soaring birds at all six studied observation points in SE Bulgaria. In contrast to our expectations, the observation area situated at greater distance from the Black Sea coast (Karnobat) showed much higher total numbers of soaring migrants than the area situated closer (Sredets). Thus, the initial hypothesis for reduced intensity of migration from the east to the west within the framework of the studied territory was not confirmed by our data. Consequently, it means that the front of Via Pontica migration route in SE Bulgaria is rather wide, since many birds cross tens of kilometres inland, at least during spring migration which is known to be more dispersed compared to the autumn migration with regard to daytime soaring migrants (CURry-Lindahl I984). Prior to our study, strong migration was reported only for the easternmost parts of Bourgas district (Michev et al. i 987 \& I999, Kostadinova \& Gramatikov 2007). As our observation points were situated in western and central parts of Bourgas district, we can conclude that in spring most of the soaring migrants cross the whole district in a wide front and they could be observed at any point of inland parts of the district. Our results showed that from all studied soaring species only the White Pelican migrates mainly close to the sea coast (observed in high numbers only at Sredets $2 \& 3$ observation points). When comparing the species composition and numbers obtained during this study to the counts made at Atanasovsko Lake, on the Black sea coast near the town of Bourgas (Michev et al. I987 \& I999, Dimitrov et al. 2005), it is obvious 
that in Sredets, and especially in Karnobat area, the White Pelican is much less numerous during spring migration. Probably White Pelicans prefer to cross the area in close vicinity of Bourgas and its adjacent wetlands due to the presence of extensive lakes where they can rest, feed and roost.

Based on our results, both observation areas could be determined as migration bottleneck sites of European importance according to the Important Bird Area (IBA) criteria B1iv and C5 of Birdlife International (HEATH \& Evans 2000), as the spring numbers of migrating storks (confirmed) and raptors (confirmed at Karnobat) exceed 5,000 and 3,000 individuals, respectively. The total numbers of migrating storks, particularly in Karnobat area (17,753 ind.), taking into consideration incomplete coverage of their migration period, almost certainly also exceed the figure of 20,000 individuals, which would characterize the area as globally important bottleneck site - covers criterion A4iv of Birdlife International (HeATH \& Evans 2000). However, one can argue against this as our areas are not typical bottleneck sites regarding their geographic features i.e. they are not mountain ridges, passes, narrow coastal plains, peninsulas etc. (ZALles \& Bildstein 2000). Considering the results of this study and several other observations from Bourgas, Yambol and Sliven districts (own data), we can predict that the annual rates of 5,000 storks and 3,000 raptors are reached at any point of the Bourgas district. In our view, a better term that should be used for similar cases, i.e. flat or gently undulating terrain without distinctive features, is "intensive migration area of soaring birds". Redfooted Falcon and Imperial Eagle also meet threshold for identification of IBAs under the A1 and C1 criteria (regular occurrence of globally threatened species, or other species of global conservation concern) in both studied observation areas. Furthermore, numbers of several congregatory species exceeds $1 \%$ of their respective flyway populations qualifying areas as IBAs of European importance (Table 5).

In Karnobat area, we detected fewer migrants during the 5-day period in May compared to the other two months of the study. There was no such difference in Sredets area, where at two observation points (Sredets $1 \& 2$ ) the 5-day period in May was the one with the highest counted total number of spring migrants. Such high figures during May were mainly due to the strong migration of White Stork at these points. Most of the mid-May flocks of White Storks are formed by non-breeding individuals as breeding of this species in most of its European range starts much earlier, during April (Newton 2008). We have regularly observed such flocks numbering hundreds of birds in Yambol and Sliven districts of SE Bulgaria until mid-June in the 2005-2010 period (own data).

Data on daily timing of migration clearly suggest that at least in Lesser Spotted Eagle individuals counted over Karnobat area and those counted over Sredets area are different to a great extent. Due to high percentage of individuals migrating in the morning time cluster, we assume many Lesser-Spotted Eagles and Black Storks spent the nights in forests in close vicinity to the south from Karnobat, the fact further enhancing the conservation value of the area.

At present, many projects for construction of wind farms along the Bulgarian Black Sea coast and in closely situated Southern Dobroudzha (NE Bulgaria) are in different stages of implementation. If most of them are finally accepted, this certainly will lead to high induced mortality of the most numerous and vulnerable migratory species registered in this study, as are storks, White Pelicans and diurnal raptors. In many studies dedicated to the birds - wind farms conflict it was emphasized that diurnal raptors are the prevailing group of birds found as victims of the collisions with turbines. They are therefore determined as birds facing higher collision risk than most other avian groups (Schwartz 2000, Madders \& Whitfield 2006, Smallwood \& Thelander 2008), which is a result of their specific behaviour (SMALlwood et al. 2009).

Wide array of factors determines the impact of wind farms on birds, especially on diurnal raptors: flight altitude, flight type (soaring, flapping, gliding), manoeuvrability and specific behaviour of birds linked to weather conditions on the one hand, and wind farm location, local topography and type of turbines installed on the other. Also, productivity, conservation status and population size of species involved are important with reference to impacts on their populations (Thelander et al. 2003, Noguera et al. 20io, European Commission 20io).

The risk of collision with wind turbines or electricity wires in our study areas could be defined as high for the following groups of birds: (1) showing mass migration - White Stork, Lesser Spotted Eagle, Common Buzzard, and also partially for Black Stork and Honey Buzzard because of their very high numbers, (2) species using mostly soaring flight i.e. like most of the recorded migrants in this study, and (3) species with heavy body mass and low manoeuvrability, e.g. the White Pelican, which was well presented at two of the observation points in Sredets area. Heavy birds with low manoeuvrability are among the common victims of wind turbines and power line wires (BEVANGer I994, Noguera et al. 20 io, European Commission 20io). 
Table 5: Soaring migratory bird species that meet Important Bird Area (IBA) criteria of BirdLife International in at least one observation area in SE Bulgaria (numbers in bold) with corresponding thresholds. Given are criteria met by separate species, threshold values and distinct geographic populations with their actual percentages for each species in observation area, where appropriate.

Tabela 5: Jadrajoče seleče se ptičje vrste, ki izpolnjujejo kriterije organizacije BirdLife International glede IBA-jev v najmanj enem opazovalnem območju v JV Bolgariji (številke v mastnem tisku) z ustreznimi pragovi. Podani so kriteriji, ki jih izpolnjujejo posamezne vrste, pragovne vrednosti in izrazite geografske populacije z dejanskimi odstotki za vsako vrsto v območju opazovanja.

\begin{tabular}{|c|c|c|c|c|c|}
\hline Species / Vrsta & $\begin{array}{l}\text { No. / Št. } \\
\text { Karnobat } \\
\text { (ind. / os.) }\end{array}$ & $\begin{array}{l}\text { No. / Št. } \\
\text { Sredets } \\
\text { (ind./ os.) }\end{array}$ & $\begin{array}{c}\text { IBA } \\
\text { Criteria/ } \\
\text { kriteriji }\end{array}$ & $\begin{array}{l}\text { Treshold/ } \\
\text { Mejna vrednost } \\
\text { (ind./ os.) }\end{array}$ & Population / Populacija \\
\hline Ciconia ciconia & $\mathrm{I} 7,4 \mathrm{I} 7$ & $5,94 \mathrm{I}$ & B1i & $4,000(\mathrm{I} \%)^{*}$ & C \& E Europe $(4.4$, I.5\%) \\
\hline Aquila pomarina & $\mathbf{I}, 930$ & $\mathrm{I}, \mathrm{I} 82$ & B1iii & $495(\mathrm{I} \%)^{* *}$ & Europe (II.7, 7.2\%) \\
\hline Ciconia nigra & 336 & 353 & $\mathrm{~B} 1 \mathrm{i}$ & $250(\mathrm{I} \%)^{*}$ & C, E Europe (I.4, I.5\%) \\
\hline Pelecanus onocrotalus & I6 & 345 & B1i & $270(\mathrm{I} \%)^{*}$ & Europe, W Asia (I.3\%) \\
\hline Falco vespertinus & 54 & 43 & $\mathrm{~A} 1, \mathrm{C} 1$ & $30^{* * *}$ & - \\
\hline Aquila heliaca & 12 & IO & $\mathrm{A} 1, \mathrm{C} 1$ & $6^{* * *}$ & - \\
\hline Total storks / Skupaj štorklje & 17,753 & 6,294 & B1iv, C5 & $5,000^{+}$ & - \\
\hline Total raptors / Skupaj ujede & 3,154 & 2,268 & B1iv, C5 & $3,000^{+}$ & - \\
\hline
\end{tabular}

* Thresholds for waterbirds, equivalent to $1 \%$ of their distinct geographic (biogeographic) populations after DeLANY \& ScOTT (2006)

** Threshold equivalent to $1 \%$ of European breeding population calculated from the estimate given in BIRDLIFE INTERNATIONAL (2004)

*** After direct recommendations from BirdLife INTERNATIONAL (unpubl.)

After Heath \& Evans (2000)

Flight altitudes of birds between 30 and $120 \mathrm{~m}$ above the ground are considered very dangerous for collision with the blades of wind turbines (NOGUERA et al. 2010). Apparently, the mean flight altitude of migrants in Sredets area coincides with the most dangerous zone of wind turbines. Due to their generally low altitude of migration in Sredets area, soaring birds could be highly vulnerable to collisions by wind farms and connected power line wires placed in that area, despite much smaller migration intensity compared to Karnobat area. Among species with the lowest flight altitudes elsewhere were Bee-eater, Red-footed Falcon, Short-toed Eagle, Montagu's C. pygargus and Marsh Harrier. For them, we can therefore predict high probability of collisions with wind turbines or power line wires. Several of these species are smaller raptors, often using active flight (flapping flight) instead of soaring. Smaller raptors, such as harriers, hawks or falcons often use flappinggliding flight, mainly after sunrise and before sunset when thermal convection is weak or absent, and more frequently in headwinds than in tailwinds (SPAAR I999). For harriers, the lowest flight altitude was reported for migrating Montagu's and Pallid Harriers (SPAAR \& Bruderer 1997) - species registered in both our observation areas. Moreover, we found evidence of Lesser Spotted Eagle night roosts, present in close vicinity to the south from Karnobat. It can be expected that early in the morning all these birds begin to gain height and initially fly rather low above the ridges, being more susceptible to collision with wind turbines. This assumption is further supported by significant influence of time cluster on the flight altitude of migrating Lesser Spotted Eagles.

It was shown that positioning of wind generators on top of the hills increases the collision risk (THELANDER at al. 2003) especially on hills with gentle slopes and weak thermals (De LuCAS et al. 2008) similar to the conditions in both observation areas in this study. Especially the Hisar Hill at Karnobat has gentle southern slopes where higher risk of bird collisions with wind turbines could be expected during spring migration period.

Taking into account that autumn migration in the studied areas could be of similar scale as spring migration or even stronger - like at the Atanasovsko Lake (Michev et al. I 999, own data), we can conclude that placing of wind farms and additional power line wires in the municipalities of Karnobat and Sredets certainly will expose many migrants to high collision risk. Hence, we recommend underground placing of new power lines in these areas. New projects for installing wind farms should avoid the area of Hissar Hill south of Karnobat and the NW parts of Sredets Municipality in the vicinity of the villages of Sredets, Svetlina, Dyulevo, Orlintsi and Suhodol. However, 
special attention should be devoted to all future wind farm projects in the Bourgas district concerning their possible negative impacts on migrating birds.

Acknowledgements: We are grateful to the companies that supplied funding for the study - Energowind BG and ENVIS, and personally to Mr. Peter Sochan (ENVIS) for their help in organizing the study. We thank our colleagues Iliyan Dimitrov and Yordan Ivanov for their participation in the field work.

\section{Povzetek}

Avtorji članka so leta 2008 preučevali intenzivnost in značilnosti spomladanske selitve jadrajočih ptic v okrožju Burgas, JV Bolgarija. V treh petdnevnih obdobjih, in sicer od 27. do 31. marca, 20. do 24. aprila in 12. do 16. maja, so seleče se ptice istočasno preštevali $s$ šestih opazovalnih točk $\mathrm{v}$ dveh različnih območjih (Karnobat in Sredets), oddaljenih 24,5 oziroma $37,3 \mathrm{~km}$ od obale Črnega morja. Skupaj so zabeležili 31.049 jadrajočih ptic, pripadajočih najmanj 27 vrstam, med katerimi je bila daleč najbolj številčna bela štorklja Ciconia ciconia (23.358 osebkov), sledil pa ji je mali klinkač Aquila pomarina (3112 os.). V območju Karnobat, ki je bolj oddaljeno od Črnega morja, je bilo skupno število jadrajočih selečih se ptic (21.231) več kot dvakrat večje kot v območju Sredets (9818), zabeležena pa je bila tudi občutna razlika v velikosti jat in višini njihovega jadranja znotraj posameznega območja (med opazovalnimi točkami) kot tudi med dvema opazovalnima območjema in tremi petdnevnimi obdobji. Hkrati je bila opažena tudi velika razlika v dejavnikih, ki v veliki meri vplivajo na velikost jat in višino leta med najbolj številčnimi posameznimi vrstami. Na splošno so ptice preletavale območje Karnobat na precej večji višini (povprečna višina leta 208,3 $\mathrm{m} \pm 6,4 \mathrm{~m}$ ) kot v območju Sredets (povprečna višina leta $130,5 \mathrm{~m} \pm 4,4 \mathrm{~m}$ ). V obeh opazovanih območjih je bila najpogosteje opažena severna smer leta (46,3\% vseh zabeleženih smeri leta). Največ selečih se jadrajočih ptic je območji preletavalo pozno popoldne, in sicer med 15. in 18. uro, ko je bilo preštetih 11.554 osebkov (43,0 \% vseh preštetih ptic). Študija je potrdila, da je fronta zahodne črnomorske selitvene poti, ali "Via Pontica" kot del mediteranskočrnomorske selitvene poti $\mathrm{v}$ JV Bolgariji, precej široka, saj lahko intenzivnost selitve prek kopnega $\mathrm{v}$ okrožju Burgas primerjamo, vsaj med spomladansko selitvijo, s tisto vzdolž črnomorske obale. Po kriterijih BirdLife International obe območji opazovanja izpolnjujeta kriterije za njuno uvrstitev med evropsko pomembna območja za ptice (IBA), avtorji prispevka pa poudarjajo, da bi se morale morebitne nove vetrne elektrarne izogniti območju hriba Hisar južno od Karnobata in SZ predelov mestne občine Sredets.

\section{References}

Bevanger, K. (1994) Bird interactions with utility structures: collision and electrocution, causes and mitigating measures. - Ibis 136: 412-425.

Cramp, S. (ed.) (1985): Handbook of the Birds of Europe, the Middle East and North Africa. The Birds of the Western Palearctic. Vol. 4. Terns to Woodpeckers. Oxford University Press, Oxford.

Curry-Lindahl, K. (I984): [Birds over land and sea. A global overview of bird migration.] - Albert Bonniers Press, Stockholm. (in Russian)

De Lucas, M., Janss, G., Whitfield, D. \& Ferrer, M. (2008): Collision fatality of raptors in wind farms does not depend on raptor abundance. - Journal of Applied Ecology 45 (6): 1695-1703.

Dimitrov, M., Michev, T., Profirov, L., Nyagolov, K. (2005): Waterbirds of Bourgas Wetlands. Results and evaluation of the monthly waterbird monitoring 1996-2002. - Bulgarian Biodiversity Foundation \& Pensoft Publishers, Sofia - Moscow.

Drewitt, A. \& Langston, R. (2006): Assessing the impacts of wind farms on birds. - Ibis 148: 29-42.

European Commission (2010): Wind energy developments and Natura 2000. EU Guidance on wind energy development in accordance with the EU nature legislation. - European Commission, Brussels.

Gyllin, R. (I97I): Notes on the spring migration of storks and raptors in Bulgaria. - Vogelwarte 26 (2): 182-185.

Heath, M.F. \& Evans, M.I. (2000): Important Bird Areas in Europe. Priority sites for conservation. Vol. 2. Southern Europe. Birdlife Conservation Series No. 8. - Birdlife International, Cambridge.

Hilgerloh, G. (2009): The desert at Zait Bay, Egypt: a bird migration bottleneck of global importance. - Bird Conservation International 19: 338-352.

Janss, G. (2000): Avian mortality from power lines: a morphologic approach of a species-specific mortality. Biological Conservation 95: 353-359.

Konigstedt, D. \& Robel, D. (I982): Über den herbstlichen Greifvogelzug an der bulgarischen Scwarzmeerkuste. Faunistische Abhandlungen 9 (15): 153-178.

Kostadinova, I. \& Gramatikov, M. (eds.) (2007): Important Bird Areas in Bulgaria and Natura 2000. Conservation Series No. 11. - Bulgarian Society for the Protection of Birds, Sofia.

Madders, M. \& Whitfield, D.P. (2006): Upland raptors and the effect of wind farm impacts. - Ibis 148: 43-56.

Michev, T., Profirov, L., Vatev, I. \& Simeonov, P. (i987): Radar investigations on the autumn migration of pelicans, storks and cranes over the Bulgarian Black Sea coast. pp. 155-158 In: Actual achievements of the Bulgarian zoology. - Bulgarian Academy of Science, Sofia.

Michev, T., Profirov, L., Dimitrov, M., \& Nyagolov, K. (I999): The birds of Atanasovsko Lake: Status and Checklist. Bourgas Wetlands Publication Series No. 1. - 
Bulgarian-Swiss Biodiversity Conservation Programme, Bourgas.

Newton, I. (2008): The migration ecology of birds. Academic Press, London.

Noguera, J., Perez, I. \& Minguez, E. (2010): Impact of terrestrial wind farms on diurnal raptors: developing spatial vulnerability index and potential vulnerability maps. - Ardeola 57 (1): 41-53.

Porter, R. \& Willis, I. (I968): The autumn migration of soaring birds at the Bosphorus. - Ibis 110: 520-536.

RoberTs, J. (1979): Observations of the migration of raptors and other large soaring birds in Bulgaria, 1975-1978. Ibis 121 (3): 301-312.

Roberts, J. (I98I): A contribution of the avifauna of Lake Atanasovsko, Bourgas. pp. 549-565 In: Proceedings of the Regional symposium under project $8 \mathrm{MAB}-$ UNESCO, 20-24 Oct 1980, Blagoevgrad. - Bulgarian Academy of Science, Sofia.

Schwartz, S.S. (ed.) (2000): Proceedings of the National Avian-Wind Power Planning Meeting IV, 16-17 May 2000, Carmel, California. - Avian Subcommittee of the National Wind Coordinating Committee \& Resolve Inc., Washington D.C.

SPAAR, R. (I999): Flight behaviour of migrating raptors under varying environmental conditions. pp. 1844-1862 In: Adams, N.J. \& Slotow, R.H. (eds.): Proceedings of the $22^{\text {nd }}$ International Ornithological Congress, 16-22 Aug 1998, Durban, - BirdLife South Africa.

SpaAR, R. \& Bruderer, B. (I 997): Migration by flapping or soaring: flight strategies of Marsh, Montagu's and Pallid Harriers in Southern Israel. - Condor 99: 458-469.

Smallwood, K.S. \& Thelander, C.G. (2008): Bird mortality at Altamont Pass wind resource area, California. - Journal of Wildlife Management 72 (1): 215-223.

Smallwood, K.S., Rugge, L. \& Morisson, M.L. (2009): Influence of behavior on bird mortality in wind energy developments. - Journal of Wildlife Management 73 (7): 1082-1098.

Thelander, C.G., Smallwood, K.S. \& Rugge, L. (2003): Bird risk behaviors and fatalities at Altamont Pass wind resource area. - National Renewable Energy Laboratory, Colorado.

Zalles, J.I. \&. Bildstein K.L. (2000): Raptor Watch: A global Directory of Raptor Migration Sites. Birdlife Conservation Series No. 8. - Birdlife International, Cambridge \& Hawk Mountain Sanctuary, Kempton.

Arrived / Prispelo: 13. 5. 2010

Accepted / Sprejeto: 19. 3. 2012 